Jurdimas (Jurnal Pengabdian Kepada Masyarakat) Royal

Vol. 4 No. 3, September 2021, hlm. 247 - 256

ISSN 2614-7912 (Print)

DOI: https://doi.org/10.33330/jurdimas.v4i3.1056

ISSN 2622-3813 (Online)

Available online at https://jurnal.stmikroyal.ac.id/index.php/jurdimas

\title{
E-BINTECH 5.0: DESA SIAGA COVID-19 BERBASIS EDUBIONEUROLITECHNOPRENEURSHIP MENUJU INDONESIA 5.0
}

\author{
Dito Anurogo ${ }^{1,2}$ Agusdiwana Suarni $^{3}$, Arli Aditya Parikesit ${ }^{4}$, Muchlis Achsan Udji Sofro ${ }^{5}$, \\ Wahyu Aristyaning Putri ${ }^{6 *}$ \\ ${ }^{1}$ Fakultas Kedokteran dan Ilmu Kesehatan, Universitas Muhammadiyah Makassar, Indonesia \\ ${ }^{2}$ International PhD Program for Cell Therapy and Regeneration Medicine (IPCTRM), Taipei \\ Medical University (TMU), Taiwan \\ ${ }^{3}$ Fakultas Ekonomi dan Bisnis, Universitas Muhammadiyah Makassar, Indonesia \\ ${ }^{4}$ Departement of Bioinformatics, School of Life Sciences, Indonesia International Institute \\ for Life Sciences \\ ${ }^{5}$ Fakultas Kedokteran Universitas Diponegoro, Semarang, Indonesia \\ ${ }^{6}$ Laboratorium Bioteknologi, Departemen Biologi Tropika, Fakultas Biologi, \\ Universitas Gadjah Mada, Yogyakarta, Indonesia \\ email: *wahyuaristyaningputri@ugm.ac.id
}

\begin{abstract}
The e-Bintech 5.0 online workshop was held to sharpen the concept of village 5.0 that is a multidisciplinary acculturation-constellation. In this workshop, multiplatform frameworks were successfully formulated as a basic guideline for village developments towards the glory of Indonesia. Pentahelix platform synergy is needed (academics, business, government, community, media) supported by relevant stakeholders for fostering a futuristic village towards the creation of Indonesia 5.0, especially in terms of ease of investment, simplification of bureaucracy and administration.
\end{abstract}

Key Words: edubioneurolitechnopreneurship; Indonesia 5.0; pentahelix; village 5.0

\begin{abstract}
Abstrak: Lokakarya daring e-Bintech 5.0 diadakan untuk menajamkan konsep desa 5.0 yang merupakan akulturasi-konstelasi multidisipliner. Dalam lokakarya ini, berhasil dirumuskan multiplatform-frameworks sebagai pedoman dasar pengembangan-pembangunan desa menuju kejayaan Indonesia. Diperlukan sinergi platform pentahelix (akademisi, bisnis, pemerintah, komunitas, media) didukung stakeholders terkait untuk pembinaan desa futuristik menuju terciptanya Indonesia 5.0, terutama dalam hal kemudahan investasi, simplifikasi birokrasi dan administrasi.
\end{abstract}

Kata Kunci: desa 5.0; edubioneurolitechnopreneurship; Indonesia 5.0; pentahelix 
Jurdimas (Jurnal Pengabdian Kepada Masyarakat) Royal

Vol. 4 No. 3, September 2021, hlm. 247 - 256

ISSN 2614-7912 (Print)

DOI: https://doi.org/10.33330/jurdimas.v4i3.1056

ISSN 2622-3813 (Online)

Available online at https://jurnal.stmikroyal.ac.id/index.php/jurdimas

\section{PENDAHULUAN}

Berdasarkan UU tentang Desa No. 6 tahun 2014 pasal 3 (Presiden RI, 2014), pengaturan desa berasaskan rekognisi, subsidiaritas, keberagaman, kebersamaan, kegotongroyongan, kekeluargaan, musyawarah, demokrasi, kemandirian, partisipasi, kesetaraan, pemberdayaan, dan keberlanjutan. Saat ini Indonesia tengah dihadapkan oleh krisis yang disebabkan oleh pandemi COVID-19. Dengan tingkat pendidikan masyarakat Indonesia yang masih kurang, kesadaran dan pemahaman akan pendidikan dan kesehatan masih belum merata. Oleh karena itu, diperlukan smart-healthy village 5.0 atau desa cerdassehat yang futuristik sebagai desa percontohan. Di era new normal, Desa Siaga COVID-19 merupakan keniscayaan. Membangun Indonesia, dimulai dari membangun desa. Desa percontohan nasional yang telah berhasil menjadi kampung siaga Covid-19 adalah Desa Jomboran di Klaten (Sardjono, 2020)

Platform penyuluhan digital ini bertujuan membentuk tenaga medis, terutama dokter dan dokter spesialis yang peduli-paham bagaimana memajukan dan memberdayakan potensi desa demi kejayaan Indonesia. Desa cerdas sehatfuturistik dapat dibangun berbasis edubio neurologi technopreneurship, yakni: edukasi, bioteknologi, biologi molekuler, biomedis, kedokteran (terutama neurosains/neurologi), kesehatan masyarakat, literasi, teknologi informasi, entrepreneurship (kewirausahaan), dan aspek lainnya yang sesuai untuk kemajuan desa, menuju terwujudnya Indonesia jaya. Aplikasi digital yang terpilih sebagai wahana penyampai adalah Doctor to Doctor (D2D) dikarenakan telah diakui secara resmi oleh Ikatan Dokter Indonesia (IDI) dan juga kanal pendidikan "Kampus Desa Indonesia" berbasis You Tube.

\section{METODE}

Metode yang dilakukan adalah deskriptif-naratif berupa seminar, diskusi interaktif, dan pembelajaran mandiri melalui media digital. Berdasarkan Term of Refference (ToR) yang telah dimusyawarahkan bersama, terdapat 12 pembicara dan 1 moderator yang setuju untuk ber-partisipasi aktif pada hari Minggu, 12 Juli 2020 dari jam 09.00 WIB hingga selesai (Gambar 1). Masing-masing pembicara mendapatkan kesempatan berbagi ilmu maksimal 15 menit atau hingga materi selesai (fleksibel). Terdapat satu pembicara (Rasyid Alfarizi) yang berhalangan hadir dikarenakan padatnya aktivitas. Flyer/poster kegiatan dijelaskan pada Gambar 1.

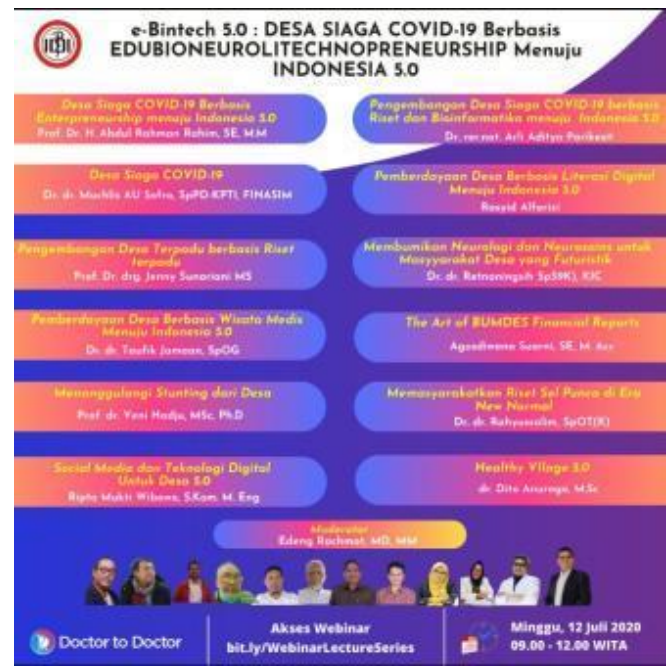

Gambar 1. Flyer Webinar

Saat webinar berlangsung, menurut catatan internal D2D, webinar ini diikuti 1867 orang, yang terdiri dari profesi koas, dokter umum, dan dokter spesialis. Webinar yang berlangsung di aplikasi D2D ini pada 18 Oktober 2020 telah diakses sekitar 12617 orang, yang terdiri dari dokter, dokter spesialis, dan pengakses aplikasi D2D. 
Jurdimas (Jurnal Pengabdian Kepada Masyarakat) Royal

Vol. 4 No. 3, September 2021, hlm. 247 - 256

ISSN 2614-7912 (Print)

DOI: https://doi.org/10.33330/jurdimas.v4i3.1056

ISSN 2622-3813 (Online)

Available online at https://jurnal.stmikroyal.ac.id/index.php/jurdimas

Tabel 1. Narasumber beserta Topik

\begin{tabular}{cll}
\hline No & Narasumber & Topik \\
\hline 1 & Abdul Rahman Rahim & $\begin{array}{l}\text { Desa Siaga Covid-19 Berbasis Enterpreneurship menuju } \\
\text { Indonesia 5.0 }\end{array}$ \\
\hline 2 & Agusdiwana Suarni & The Art of BUMDES Financial Reports \\
\hline 3 & Arli Aditya Parikesit & $\begin{array}{l}\text { Pengembangan Desa Siaga Covid-19 berbasis Riset dan } \\
\text { Bioinformatika menuju Indonesia 5.0 }\end{array}$ \\
\hline 4 & Dito Anurogo & Healthy and Smart Village 5.0 \\
\hline 5 & Jenny Sunariani & Pengembangan Desa Terpadu berbasis Riset Terpadu \\
\hline 6 & Muchlis A. Udji Sofro & Desa Siaga COVID-19 \\
\hline 7 & Rahyussalim & Memasyarakatkan Riset Sel Punca di Era New Normal \\
\hline 8 & Retnaningsih & $\begin{array}{l}\text { Membumikan Neurologi dan Neurosains untuk } \\
\text { Masyarakat Desa yang Futuristik }\end{array}$ \\
\hline 9 & Ripto Mukti Wibowo & Social Media dan Teknologi Digital untuk Desa 5.0 \\
\hline 10 & Taufik Jamaan & $\begin{array}{l}\text { Pemberdayaan Desa berbasis Wisata Medis menuju } \\
\text { Indonesia 5.0 }\end{array}$ \\
\hline 11 & Veni Hadju & Menanggulangi Stunting dari Desa \\
\hline 12 & Wahyu Aristyaning Putri & Belajar Membangun Desa dari Jepang \\
\hline
\end{tabular}

Webinar yang berlangsung selama 4 jam 27 menit 55 detik ini juga dapat diakses melalui Youtube. Adapun kanal pendidikan "Kampus Desa Indonesia" berbasis You Tube (Gambar 2.)

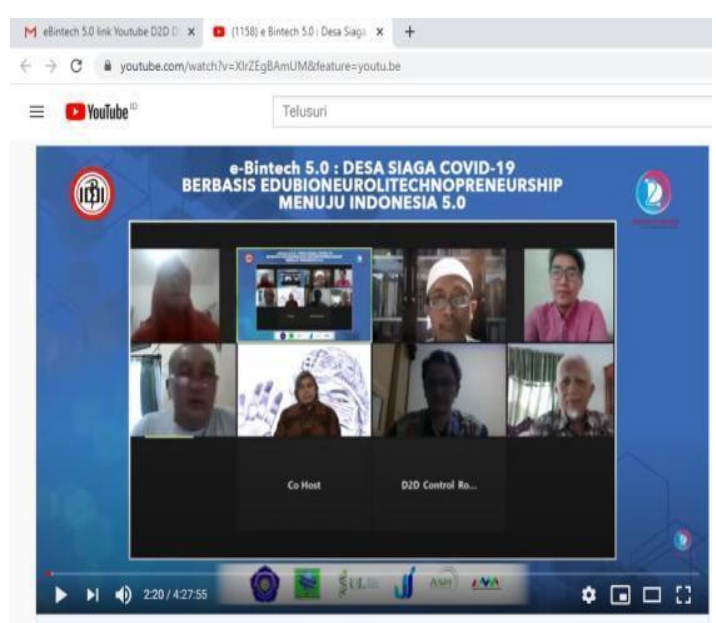

Gambar 2. Kondisi Webinar

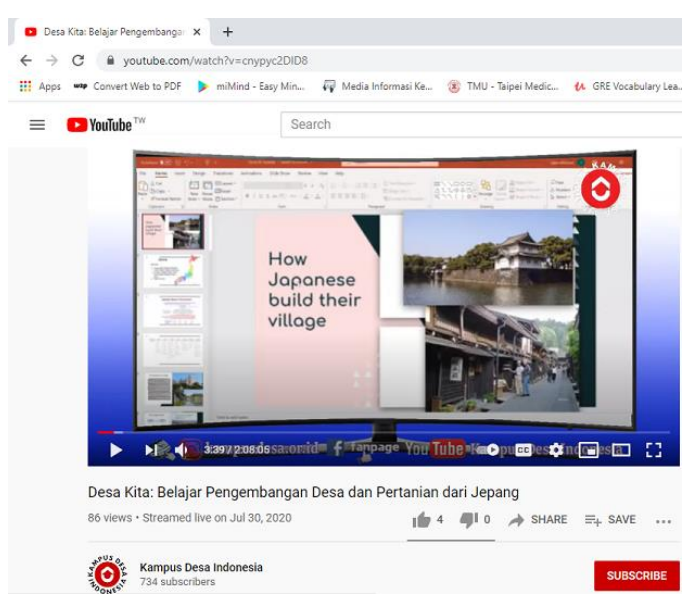

Gambar 3. Kondisi Seminar lanjutan di Kanal pendidikan Kampus Desa Indonesia

\section{PEMBAHASAN}

Kegiatan webinar ini membahas 12 topik dari 12 narasumber (Tabel 1). Abdul Rahman Rahim memaparkan tentang Desa Siaga Covid-19 berbasis 
Available online at https://jurnal.stmikroyal.ac.id/index.php/jurdimas

Entrepreneurship menuju Indonesia 5.0. Masyarakat 5.0 (society 5.0) merupakan masyarakat yang berkesinambungan di mana semua orang dapat hidup dengan aman, nyaman, dan sejahtera. Masyarakat 5.0 ditandai dengan lima kemajuan. Pertama, layanan kesehatan, medis, dan keperawatan. Kedua, mobilitas tinggi, cepat, namun tetap nyaman di komunitas. Ketiga, produksi tinggi, namun sampah semakin tereliminasi. Keempat, infrastruktur dan perkembangan desa dan lingkungan sekitarnya (urban development) dirancang anti gempa serta tanggap-tangguh bencana. Kelima, kenyamanan transaksional dan kemudahan prosedur finansial. Pelayanan, pemberdayaan masyarakat, dan pembangunan perlu memperhatikan beberapa komponen, yakni: pemerintah, masyarakat, institusi, sektor swasta, dan pemimpin komunitas (tokoh masyarakat). Di antara pelbagai komponen ini perlu penguatan, pemberdayaan, pergerakan, partisipasi, dan tanggung-jawab. Faktor regulasi, kebijakan, fasilitas juga berperan penting dalam proses penggerakan dan pola jejaring pemberdayaan masyarakat. Kerangka teoritis pemberdayaan masyarakat, meliputi: developmentalisme, pemberdayaan masyarakat, partisipatif, program pemberdayaan, dan welfare state (Fedi, Mannarini, \& Maton, 2009).

Agusdiwana Suarni menjelaskan tentang The Art of BUMDES Financial Reports. Salah satu alternatif pemberdayaan produktif masyarakat desa adalah dengan mendirikan Badan Usaha Milik Desa (BUMDes). Menurut Permendes (2015), BUMDes adalah badan usaha yang seluruh atau sebagian besar modalnya dimiliki oleh desa melalui penyertaan secara langsung yang berasal dari kekayaan desa yang dipisahkan guna mengelola aset, jasa pelayanan, dan usaha lainnya untuk sebesar-besarnya ke- sejahteraan masyarakat desa. Definisi ini juga serupa dengan UU No 06 Tahun 2014 tentang desa. Berdasarkan Permendes No 4 Tahun 2015 pasal 3, pendirian BUMDes bertujuan meningkatkan perekonomian desa, mengoptimalkan aset desa agar bermanfaat untuk kesejahteraan desa, meningkatkan usaha masyarakat dalam pengelolaan potensi ekonomi desa, mengembangkan rencana kerja sama usaha antar desa dan/atau dengan pihak ketiga, menciptakan peluang dan jaringan pasar yang mendukung kebutuhan layanan umum warga, membuka lapangan kerja, meningkatkan kesejahteraan masyarakat melalui perbaikan pelayanan umum, pertumbuhan dan pemerataan ekonomi desa, dan meningkatkan pendapatan masyarakat desa dan pendapatan asli desa. BUMDes dibentuk atas dasar semangat kekeluargaan, dan kegotongroyongan untuk mendayagunakan segala potensi ekonomi, kelembagaan perekonomian, serta potensi sumber daya alam, dan sumber daya manusia dalam rangka meningkatkan kesejahteraan masyarakat (Marala, Wibowo, \& Kurniawan, 2019).

$$
\text { Arli Aditya Parikesit }
$$
memaparkan tentang Pengembangan Desa Siaga Covid-19 berbasis Riset dan Bioinformatika menuju Indonesia 5.0.(Parikesit, Pradana, Ratnasari, \& Anurogo, 2021). Beberapa poin penting dari paparannya: 1. Kecerdasan Buatan (AI) sudah dimanfaatkan untuk menghadapi pandemi COVID-19; 2. Aplikasi AI seperti robot asisten tenaga kesehatan (nakes) di rumah sakit dan klinik. Wisma Atlet dan RS UNAIR sudah mulai menggunakan teknologi robotik tersebut; 3. AI tidak akan menggantikan nakes dan aparat desa. Mereka akan menyempurnakan tugas 
nakes dan aparat desa (Hanania). Berikut beberapa aplikasi AI untuk publik. Pertama, secara cerdas mengotomatisasi administrasi, menjalankan fungsi end-toend automation, membaca dan memvalidasi dokumentasi, manajemen kasus intelijen. Kedua, berinteraksi dengan warga negara dan pegawai pemerintah, menambah pengalaman warga negara, menjalankan peran sebagai AI conversational, berinteraksi dengan pegawai pemerintah. Ketiga, mendeteksi anomali, mendeteksi situasi berbahaya, mendeteksi fraud dan kriminal, serta solusi 24/7 (alias 24 jam dan 7 hari, berkesinambungan). Keempat, membantu proses pengambilan keputusan, menjalankan fungsi insights driven action, augmenting civil servants (memberdayakan pegawai negeri), membantu proses analisis prediktif (memperkirakan) dan preskriptif (menentukan) (Benke \& Benke, 2018).

Dito Anurogo menjelaskan tentang Healthy and Smart Village 5.0. Berikut ini sembilan karakteristik Desa Sehat (Healthy Village). Pertama, memperhatikan aspek kebersihan dan keselamatan lingkungan. Kedua, mampu menciptakan ekuilibrium sosial melalui partisipasi/intervensi komunitas bersama seluruh warga. Ketiga, komunitas lokal memiliki akses ke berbagai pengalaman, interaksi, dan komunikasi. Keempat, melestarikan tradisi, adat-istiadat, warisan sosio kultural historis. Kelima, memiliki layanan kesehatan sesuai standar dan kebutuhan warga serta mudah diakses. Keenam, memiliki sektor ekonomi yang beragam dan inovatif. Ketujuh, menggunakan sumber daya yang berkelanjutan untuk memberdayakan komunitas lokal. Kedelapan, mampu meningkatkan kualitas hidup mayoritas warga. Kesembilan, mampu membantu masalah kesehatan utama Negara
(Howard, 2002). Salah satu contoh desa sehat adalah Desa Bungur, Kecamatan Tulakan, Kabupaten Pacitan, Provinsi Jawa Timur. Hal ini tertuang di Peraturan Desa Bungur Nomor: 08 Tahun 2017. Adapun desa cerdas (smart village) bercirikan: pendekatan bottomup, posisi pemerintah sebagai fasilitator, posisi masyarakat sebagai customer, proses pengembangannya melalui penguatan, kesadaran, dan partisipasi terhadap elemen smart village, prioritas sasarannya: masyarakat menengah, miskin, dan belum terberdayakan, prasyarat keberhasilan: pendekatan sosiokultural menjadi basis utama.

Adanya identifikasi yang valid terhadap berbagai nilai, karakter, norma, dan masalah yang ada di masyarakat menjadi dasar keberhasilan smart village. Bertujuan: mewujudkan pemberdayaan, penguatan kelembagaan, peningkatan kesejahteraan masyarakat pedesaan yang didasarkan atas pemanfaatan teknologi informasi (Rini Rachmawati, 2018).

Jenny Sunariani menjelaskan tentang Pengembangan Desa Terpadu berbasis Riset Terpadu. Desa merupakan wilayah yang jauh dari pusat keramaian kota. Kondisi di desa cenderung masih alami, jumlah penduduknya sedikit, banyak lahan kosong yang umumnya dimanfaatkan untuk bertani dan berkebun. Masyarakat kota dan desa saling membutuhkan. Tanpa masyarakat desa, orang-orang yang berada di kota tidak akan terpenuhi kebutuhan pokoknya. Begitupun sebaliknya, hasil yang mereka tanam akan dijual pada masyarakat kota guna memenuhi kebutuhan mereka di desa.

Terdapat beberapa program Inovasi desa. Misalnya: 1. Air Sungai sebagai Pembangkit listrik Tenaga 
Mikro Hidro (PLTMH); 2. Teknologi Sumur Sebagai Ketersediaan Air Desa; 3. Desa Konservasi Bambu Untuk Menjaga Sumber Mata Air Dan Debit Air Embung Pertanian; 4. Penyusunan Ulang Informasi Kepemilikan Tanah Warga; 5. Mengaktifkan Kembali Bumdes Yang Dibekukan; 6. Desa Mengubah Limbah Minyak Goreng Menjadi PAD; 7. Pemanfaatan tenaga ahli untuk pengembangan Usaha Desa; 8. Membangun Sekolah Untuk Memenuhi Kebutuhan Pendidikan; 9. Membuka Pusat Kegiatan Belajar Masyarakat; 10. BPJS Desa Mandiri oleh Organisasi Kesehatan Masyarakat (OKM) desa. Program inovasi desa ini sebagai implementasi dari Peraturan Menteri Kesehatan Republik Indonesia No 8 Tahun 2019 tentang Pemberdayaan Masyarakat Bidang Kesehatan (Kemenkes RI, 2019).

Muchlis Achsan Udji Sofro menjelaskan tentang Desa Siaga COVID19. Terdapat percontohan Desa Siaga Covid-19. Pertama, Desa Bulupayung, Kecamatan Kesugihan, Cilacap, Jawa Tengah (Bintoro, 2020). Kedua, Desa Jomboran, Klaten Tengah, Jawa Tengah (Sardjono, 2020). Siklus Pemberdayaan Masyarakat dalam Pencegahan COVID19 dilakukan melalui enam tahapan. Pertama, pendataan kesehatan warga di RT/RW/Desa. Kedua, identifikasi faktor penyebab penularan COVID-19 dan potensi wilayah. Ketiga, musyawarah masyarakat RT/RW/Desa. Keempat, menyusun rencana kegiatan. Kelima, pelaksanaan kegiatan. Keenam, keberlangsungan kegiatan. Dari tahapan keenam kembali ke tahapan pertama, dan begitu seterusnya (BNPB, 2020).

Lima strategi penanganan Covid19 di desa. Pertama, menghubungi petugas medis dan Gugus Tugas Covid-19 Kabupaten untuk penanganan warga yang diisolasi. Kedua, melaporkan pasien dalam pengawasan (PDP) ke Puskesmas/Gugus Tugas Covid-19 di Kabupaten. Ketiga, menyiapkan logistik bagi orang dalam pantauan (ODP) selama berada di ruang isolasi. Keempat, menempatkan ODP ke ruang isolasi yang telah disiapkan. Kelima, bekerja sama dengan RS rujukan dan/puskesmas setempat (Kemenkes RI, 2020).

Rahyussalim memaparkan tentang Memasyarakatkan Riset Sel Punca di Era New Normal. Sel punca diyakini dapat digunakan untuk mengisi dan memperbaharui sel jaringan yang rusak akibat berbagai penyakit. Sel punca memiliki karakteristik 4R, yakni: Replace, Restore, Regenerate, dan Rejuvenate (Pavlovic \& Radotic, 2017). Mengapa perlu melakukan riset sel punca? Tren penyakit saat ini, meliputi: degenerative, cancer, trauma, metabolik, inherent, dan sebagainya. Kesemuanya itu belum memiliki terapi pasti. Terapi sel punca sebagai salah satu pilihannya. Riset sel punca meliputi: studi in vitro, studi klinis, dan studi in vivo. Masyarakat perlu diperkenalkan tentang riset dan implementasi sel punca dalam mengatasi suatu masalah atau penyakit (Biehl \& Russell, 2009).

Retnaningsih memaparkan tentang Membumikan Neurologi dan Neurosains untuk Masyarakat Desa yang Futuristik. Perbedaan fasilitas perdesaan dan perkotaan dipengaruhi multifaktor. Pertama, sikap dan pengetahuan. Masyarakat pedesaan cenderung memiliki sikap pasrah dan pengetahuan yang kurang. Masyarakat perkotaan cenderung memiliki sikap kritis dan pengetahuan yang tinggi. Kedua, pelayanan kesehatan. Fasilitas pelayanan kesehatan di pedesaan 
Available online at https://jurnal.stmikroyal.ac.id/index.php/jurdimas

cenderung terbatas, akses terhadap keterangan dan informasi kesehatan terbatas, dan keterjangkauan kurang karena tidak didukung faktor geografi dan ekonomi. Fasilitas pelayanan kesehatan di perkotaan cenderung bagus karena dukungan faktor geografi dan ekonomi. Ketiga, kependudukan. Kepadatan penduduk di pedesaan masih relatif rendah dengan keturunan yang relatif homogen. Kepadatan penduduk di perkotaan tinggi dengan keturunan yang heterogen. Maksudnya, terdiri dari beragam suku bangsa (Saprodi, 2015).

Ripto Mukti Wibowo memaparkan tentang Social Media dan Teknologi Digital untuk Desa 5.0. Desa Digital (digital village) membahas konsep tentang pengembangan desa dengan memanfaatkan teknologi digital dan internet baik dalam pelayanan publik maupun pengembangan kawasan dan potensi desa, seperti infrastruktur, pemasaran, teknologi informasi, komunikasi, transportasi, zonasi, irigasi, drainase, dan energi. Dengan desa digital diharapkan mampu untuk menurunkan biaya dan meningkatkan pelayanan publik serta taraf hidup masyarakat desa.

Di Indonesia, terdapat sejumlah desa digital. Misalnya: Desa Lamahu, Kabupaten Bone Bolango, sebagai Desa Digital Percontohan tahun 2017. Desa ini telah menggunakan sistem command center dengan CCTV di tiap sudut jalan yang digunakan untuk memudahkan tindak lanjut cepat tanggap akan kondisi darurat Kamtibmas maupun darurat kesehatan. Desa ini juga menggunakan aplikasi berbasis Android untuk memudahkan pelayanan kependudukan dan penyampaian aspirasi masyarakat (Azhar, 2019).

$$
\text { Veni Hadju menjelaskan }
$$

problematika bertema Menanggulangi Stunting dari Desa. Stunting adalah kondisi gagal tumbuh pada anak balita akibat kekurangan gizi kronis sehingga anak lebih pendek untuk usianya. Hal ini disebabkan karena kekurangan gizi, yang terjadi sejak bayi dalam kandungan dan di masa awal kehidupan. Singkatnya, stunting merupakan kondisi anak pendek akibat kurang gizi kronis dan adanya penyakit infeksi. Di tingkat negara, stunting memiliki dampak signifikan. Misalnya: menghambat pertumbuhan dan ekonomi, menurunkan produktivitas kerja, berkurangnya $11 \%$ Gross domestic product (GDP), turunnya pendapatan pekerja dewasa hingga $20 \%$ (World Bank Group, 2016). Status gizi dan kesehatan ibu dan anak sebagai penentu kualitas sumber daya manusia, semakin jelas dengan adanya bukti bahwa status gizi dan kesehatan ibu pada masa pra-hamil, saat kehamilannya dan saat menyusui merupakan periode yang sangat kritis. Apabila dihitung dari sejak hari pertama kehamilan, kelahiran bayi sampai anak usia 2 tahun, maka periode ini merupakan periode 1000 hari pertama kehidupan manusia. Periode ini telah dibuktikan secara ilmiah merupakan periode yang menentukan kualitas kehidupan. Oleh karena itu periode ini ada yang menyebutnya sebagai "periode emas" atau "periode kritis". Bank Dunia di tahun 2006 menyebutnya sebagai "window of opportunity". Walaupun remaja putri secara eksplisit tidak disebutkan dalam 1000 hari pertama kehidupan (HPK), namun status gizi remaja putri atau pranikah memiliki kontribusi besar pada kesehatan dan keselamatan kehamilan dan kelahiran, apabila remaja putri menjadi ibu. Periode seribu hari, yaitu 270 hari selama kehamilannya dan 730 hari pada kehidupan pertama bayi yang 
dilahirkannya, merupakan periode yang sensitif karena akibat yang ditimbulkan terhadap bayi pada masa ini akan bersifat permanen dan tidak dapat dikoreksi.

Wahyu Aristyaning Putri dalam seminar lanjutan menjelaskan tentang "Belajar Membangun Desa dari Jepang" (Gambar 3). Dahulu, Jepang adalah kumpulan dari kerajaan-kerajaan kecil yang kemudian berkembang dan bersatu di era Restorasi Meiji menjadi sebuah "Negara"(Phipps, 2018). Demikian pula pertanian di Jepang telah mengalami perkembangan dari pertanian yang bersifat tradisional menjadi pertanian modern dengan teknologi tinggi. Perkembangan teknologi pertanian di Jepang ditandai dengan adanya "Smart Agriculture Technologies", JFOODO “All Japan" promotion yang merupakan pusat promosi pertanian terpadu, GAP (Good Agricultural Practise) yang merupakan pusat pelatihan dan peningkatan skill untuk para petani, HACCP (Hazard Analysis dan Critical Control Point) yang merupakan pusat quality control untuk setiap hasil pertanian (Morimoto \& Hayashi, 2017). Selain potensi pertanian, perikanan dan kehutanan di Jepang potensi wisata juga menjadi daya tarik tersendiri.

Desa wisata berkembang dari potensi desa dan kesadaran masyarakatnya untuk mengembangkan desanya. Hal ini juga didukung dengan kepedulian pemerintah pusat berupa kebijakan yang mendukung desa wisata termasuk adanya program promosi terpadu yang dikelola oleh organisasi pemerintah (MILT, 2019). Potensi desa yang dapat dikembangkan menjadi industri pariwisata Antara lain, keindahan alam, makanan khas/tradisional, situs sejarah, pertanian, keunikan wilayah, pendidikan, festival adat dan kebudayaan.

\section{SIMPULAN}

Desa 5.0 merupakan suatu pengembangan wilayah berbasis komunitas multikompleks yang lintasmultidisipliner, melibatkan aspek edukasi, bioinformatika, biologi molekuler, kedokteran (termasuk neurologineurosains), kesehatan masyarakat, teknologi informasi, sosial-ekonomi (seperti: kewirausahaan). Desa 5.0 juga bisa memanfaatkan teknologi tingkat lanjut seperti mendevelop suatu riset (sel punca) dan kecerdasan buatan (AI), namun hal tersebut akan memerlukan strategi yang bersifat kolaboratif. Berbagai platform desa di Jepang dapat menjadi model (benchmark) untuk terwujudnya desa futuristik, desa Siaga Covid-19, dan Desa 5.0. Diperlukan sinergi-kolaborasi platform pentahelix ABGCM (akademisi, bisnis, pemerintah, komunitas, media) didukung stakeholders lain untuk pengembangan desa futuristik menuju terciptanya Indonesia 5.0, terutama dalam hal kemudahan investasi, simplifikasi birokrasi dan administrasi.

\section{UCAPAN TERIMAKASIH}

Ucapan terimakasih kepada Lembaga Penelitian Pengembangan dan Pengabdian Masyarakat (LP3M) Universitas Muhammadiyah (Unismuh) Makassar, yang telah mendanai aktivitas pengabdian masyarakat ini. Ucapan terimakasih yang sama kepada: International PhD Program for Cell Therapy and Regenerative Medicine (IPCTRM) Taipei Medical University (TMU) Taiwan, Indonesia International Institute for Life Sciences (I3L), Asosiasi Sel Punca Indonesia (ASPI), Wibawa Solution, Inc., Belajar- 
berbagi.ID, Fakultas Kedokteran Universitas Indonesia (FKUI) Jakarta, Asosiasi Wisata Medis Indonesia (AWMI), RSUP Dr Kariadi Semarang, Fakultas Kedokteran Universitas Diponegoro (FK UNDIP) Semarang, Fakultas Kedokteran Gigi Universitas Airlangga (FKG Unair) Surabaya, Fakultas Kesehatan Masyarakat Universitas Hasanuddin (FKM Unhas) Makassar, Sahabat Literasi Indonesia, Jenewa Institute, School of Life Institute, Universitas Gadjah Mada, atas dukungan dan supervisinya sehingga kegiatan daring ini dapat terselenggara dengan optimal dan berkesinambungan.

\section{DAFTAR PUSTAKA}

Azhar, R. A. (2019). Lamahu, Desa Digital Pertama di Indonesia. Retrieved from https://regional.kompas.com/read/ 2017/04/07/07070001/lamahu.desa .digital.pertama.di.indonesia

Benke, K., \& Benke, G. (2018). Artificial intelligence and big data in public health. International Journal of Environmental Research and Public Health, 15(12). https://doi.org/10.3390/ijerph1512 2796

Biehl, J. K., \& Russell, B. (2009). Introduction to Stem Cell Therapy. Journal of Cardiovascular Nursing, 24(2), 98-103. https://doi.org/10.1097/JCN.0b013 e318197a6a5

Bintoro, D. (2020). Cilacap Tetapkan Desa Siaga Covid-19 Pertama Di Bulupayung.

BNPB. (2020). Strategi Komunikasi Perubahan Perilaku (KPP) Dalam Pencegahan Covid-19. 1-48.

Fedi, A., Mannarini, T., \& Maton, K. I.
(2009). Empowering Community Settings and Community Mobilization. Community Development, 40(3), 275-291.

https://doi.org/10.1080/1557533 0903109985

Howard, G. (2002). Personal, domestic and community hygiene. Healthy Villages: A Guide for Communities and Community Health Workers, 65-73.

Kemenkes RI. Peraturan Menteri Kesehatan Republik Indonesia Nomor 8 Tahun 2019 Tentang Pemberdayaan Masyarakat Bidang Kesehatan. , (2019).

Kemenkes RI. (2020). Pedoman Pemberdayaan Masyarakat dalam Pencegahan COVID-19. Retrieved from https://covid19.go.id/edukasi/ma syarakat-umum/pedomanpemberdayaan-masyarakatdalam-pencegahan-covid-19-dirtrwdesa

Marala, R., Wibowo, H., \& Kurniawan, R. R. (2019). Model Pengelolaan Badan Usaha Milik Desa (BUMDes) Dalam Membangun Perekonomian Desa (Studi Kasus Desa Masalima). Jurnal Ekonomi Dan Perbankan Syariah, 6(1), 107-134. https://doi.org/10.46899/jeps.v6i 1.90

MILT. (2019). White Paper On Land, Infrastructure, Transport And Tourism In Japan. Retrieved from https://www.mlit.go.jp/common/ 001325161.pdf

Morimoto, E., \& Hayashi, K. (2017). Design of Smart Agriculture Japan Model. Advances in Animal Biosciences, 8(2), 713- 
Jurdimas (Jurnal Pengabdian Kepada Masyarakat) Royal

Vol. 4 No. 3, September 2021, hlm. 247 - 256

DOI: https://doi.org/10.33330/jurdimas.v4i3.1056

Available online at https://jurnal.stmikroyal.ac.id/index.php/jurdimas

717.

https://doi.org/10.1017/s20404700 17000371

Parikesit, A. A., Pradana, Ratnasari, N. R., \& Anurogo, D. (2021). Application of Artificial Intelligence-Based Computation in the Health Sciences to Ward off the COVID-19 Pandemic. International Journal of Human and Health Sciences, 05(02), 177184.

https://doi.org/10.1177/146144481 0365020

Pavlovic, M., \& Radotic, K. (2017). Animal and Plant Stem Cells: Concepts, Propagation and Engineering. Animal and Plant Stem Cells: Concepts, Propagation and Engineering, 1234. https://doi.org/10.1007/9783-319-47763-3

Phipps, C. (2018). Introduction: 'Meiji Japan in global history.' Japan Forum, 30(4), 443-451. https://doi.org/10.1080/09555803. 2018.1538160

Presiden RI. Undang-Undang Republik Indonesia Nomor 6 Tahun 2014
Tentang Desa. , (2014).

Rini Rachmawati. (2018).

Pengembangan Smart Village untuk Penguatan Smart City dan Smart Regency. Jurnal Sistem Cerdas, 1(2), 12-19. https://doi.org/10.37396/jsc.v1i2 .9

Saprodi, E. (2015). Perbedaan Masyarakat Perkotaan Dan Masyarakat Pedesaan Dari Berbagai Aspek. Retrieved from https://www.academia.edu/2858 8788/Perbedaan_Masyarakat_Pe rkotaan_Dan_Masyarakat

Sardjono, D. (2020). Desa Jomboran Jadi Kampung Siaga Covid-19 di Klaten Djoko. Media Indonesia, pp. 1-9. Retrieved from

https://mediaindonesia.com/nusa ntara/303563/desa-jomboranjadi-kampung-siaga-covid- 19di-klaten

World Bank Group. (2016). Investing in the early years for Growth and productivity. 8-9. 